\title{
sciendo
}

DOI: 10.2478/orga-2019-0005

\section{Occupational Stress, Symptoms of Burnout in the Workplace and Work Satisfaction of the Age-diverse Employees}

\author{
Maja ROŽMAN ${ }^{1}$, Anastasiia GRINKEVICH ${ }^{2}$, Polona TOMINC ${ }^{1}$
}

\author{
${ }^{1}$ University of Maribor, Faculty of Economics and Business, Razlagova 14, 2000 Maribor, Slovenia \\ maja.rozman1@um.si, polona.tominc@um.si \\ ${ }^{2}$ National Research Tomsk State University, Institute of Economics and Management, \\ Lenin Ave. 36, 634050 Tomsk, Russian Federation \\ tasya-g89@mail.ru
}

\begin{abstract}
Background and Purpose: Age diverse employees are faced with different types of occupational stress and different symptoms of burnout when carrying out their work. Therefore, the role of age in job design and implementation of work should not be ignored. The main aim of this paper is to investigate the age differences of occupational stress and symptoms of burnout of employees and to analyze the impact of occupational stress, symptoms of burnout and age on employees' work satisfaction.

Methodology: The paper is based on research that includes a survey of employees in two age groups: younger employees under 50 years of age and older employees between 50 to 65 years of age. Factor analysis was used to form the constructs of occupational stress, symptoms of burnout and employees' work satisfaction. The non-parametric Mann-Whitney $U$ test was used to test differences in the obtained constructs of occupational stress and symptoms of burnout in the workplace between two independent groups. The multiple regression analysis was used to examine the impact of occupational stress, symptoms of burnout and age on employees' work satisfaction.

Results: The results show there are statistically significant differences in occupational stress and symptoms of burnout in the workplace between older and younger employees. On average, younger employees perceived higher levels of occupational stress and burnout as compared to the older group. Research results also show that occupational stress, behavioral symptoms and emotional symptoms of burnout, as well as age, have a significant impact on employees' work satisfaction.

Conclusion: Managing diversity requires a strategic approach to managing people at work. Therefore, this research adds to the body of knowledge by pointing out the relationship between age and occupational stress and burnout symptoms. Because the role of age in job design has largely been ignored, these relationships have not been studied enough.
\end{abstract}

Keywords: Occupational stress; burnout; symptoms of burnout; age-diverse employees; work satisfaction

Received: November 10, 2018; revised: January 4, 2019; accepted: January 26, 2019 


\section{Introduction}

Job design is of special importance in contemporary human resource management. It is essential to design jobs so that stress can be reduced, motivation can be enhanced and the satisfaction of employees and their performance can be improved to ensure that organizations can effectively compete in the global marketplace (Garg and Rastogi, 2006). Stressful, depressed and dissatisfied employees are not able to obtain the same quality level of work and productivity as those employees with low stress and high satisfaction (George and Zakkariya, 2015). It is essential that the employees' psychological aspects are considered. Employers should create a safe, stress-reduced environment in which to work.

Further, it has become important to understand the role of individuals' differences in examining the effects of job characteristics on job attitudes (Morgeson and Humphrey, 2006). This means that job characteristics are not experienced in the same way by all groups of workers (Zaniboni et al., 2014). Due to demographic changes in most industrialized countries, the average age of working people is continuously increasing and the workforce is becoming more age diverse (Hertel et al., 2013). Zaniboni et al. (2014) demonstrated that the role of age in the relationship between job characteristics and job attitudes is important; with the ageing population it is necessary to see how jobs might be redesigned to enable people to continue to work successfully. It is also appropriate to examine the interplay between age and work characteristics because people generally spend a significant part of their lifespan working, and, therefore, have ample opportunity to display these adaptive processes throughout their working lives. Yet the role of age in job design has largely been ignored (Truxillo et al., 2012). Satisfied employees are a vital prerequisite for a "healthy" company (Halkos and Bousinakis, 2010); it is important that employers create a safe and friendly work environment (George and Zakkariya, 2015).

Demographic changes caused by the ageing of the population have an impact on organizations and the age structure of their employees; organizations face new challenges in the field of human resources management since employees belonging to different age groups also perceive their working environment differently and react differently. The first step towards the adequate management of age diverse employees is to create an appropriate working environment that dictates the successful result of ageing for employees, and, thus, facilitates the achievement of goals, performance and competitiveness of the company (see, e.g., Jolynn et al., 2011; Ilmarinen, 2006). Robertson and Cooper (2010) found that low levels of stress, high levels of psychological well-being and the work satisfaction of older and younger employees play a central role in delivering the important outcomes associated with success in companies.
This paper aims to answer the following research questions: (1) RQ1: Are there statistically significant differences in occupational stress in the workplace of older employees as compared to younger employees in Slovenian companies? (2) RQ2: Are there statistically significant differences in the symptoms of burnout of older employees as compared to younger employees in Slovenian companies? (3) RQ3: Do occupational stress, symptoms of burnout and age have a significant impact on the employees' perceived work satisfaction?

Therefore, the main objectives of this paper are: (i) to investigate the differences between occupational stress and symptoms of burnout of employees from different age groups in the workplace and (ii) to analyze the impact of occupational stress, symptoms of burnout and age on work satisfaction of employees.

\section{Literature Review}

\subsection{Occupational stress}

Occupational stress is defined as "the harmful physical and emotional responses that occur when the requirements of the job do not match the capabilities, resources or needs of the worker" (De Silva et al., 2017). Consequences of occupational stress are observed at two levels, at the company level and at the level of the worker, and there is a correlation between the two; economic losses within a company correlates (affects) employees' health state (Mosadeghrad, 2014). Workers not capable of coping with stressful situations might face a variety of negative effects in their physical, psychological or behavioral states. In the physical area, people may feel different pains such as headaches, neck pain and shoulder pain or have an elevated heart rate. In the psychological area negative effects may include insomnia, anxiety, depression and other psychological issues. Behavioral factors include fatigue, less efficacy at work and many others; these factors will influence in a negative way the entire production, the branch's image and the quality of the final consumer product (Hespanhol, 2004). Research on the harmful effects of occupational stress on physical well-being and a worker's health show that among principal consequences are higher risks for cardiovascular diseases (Kang et al., 2005), musculoskeletal disorders, respiratory diseases, psychological disorders, sleep disturbances, lack of concentration, depression, intolerance and many others, as well as anxiety ( $\mathrm{O}^{\prime}$ Connor et al., 2000).

According to Hertel et al. (2013) older employees experience lower stress levels than younger employees. On the other hand, Götz et al. (2018) emphasized that the impact of stressful work differs depending on the period, or life stage, at which it occurs. Older persons may be more vulnerable to occupational stress because the ageing pro- 
cess is accompanied by changes in coping capabilities and resources as well as changes of the physiological system. Older employees, therefore, may be more likely to become sick in the case of stressful work and may take longer to recover from illness. In that case, the association between stress and sickness absences would be more pronounced for older employees. The authors also argue that younger employees may face greater pressure to develop strong ties to the labour market, and therefore, they are more likely to continue working, compared to their older counterparts, even if conditions at work are poor. There are, however, also reasons why the association between occupational stress and sickness absence could be less pronounced for older employees than for younger employees. For example, older employees may face more difficulties in finding a new job in the case of job loss; therefore, they are probably more likely to tolerate adverse conditions than younger employees.

\subsection{Burnout and symptoms of burnout}

Occupational stress related to a severe and constant level of stress is known as burnout syndrome, which is characterized by a decrease in personal fulfillment, isolation from social relationships and emotional exhaustion (Yavas et al., 2013). Maslach et al. (2001) defined burnout as a "prolonged response to chronic emotional and interpersonal stressors on the job, and is defined by the three dimensions of exhaustion, cynicism, and inefficacy". Also, the authors summarized research that indicates burnout has been associated with various forms of job withdrawal (absenteeism), intention to leave the job and actual turnover.

In our research, the burnout of employees was identified and measured by three separate groups of symptoms. Physical symptoms of burnout include exhaustion, fatigue, headaches, sleep disorders, loss of energy, nonspecific pain, reduced attention span, feelings of meaninglessness, apathy, raised blood pressure, chest pains and gastrointestinal disorders. Emotional symptoms of burnout in the workplace may include depressed mood states, anxiety, irritability, loss of confidence, tension or sadness. Behavioral symptoms of burnout in the workplace may include disturbed sleep patterns, reduced reaction times, reduced work capacity and less work motivation (Mosadeghrad, 2014).

\subsection{Satisfaction in the workplace}

Job satisfaction generally implies a positive evaluation of work and a positive effect deriving from it; that is, a "positive emotional state resulting from the appraisal of one's job or job experiences" (see, e.g., Tansel and Gazîğlu, 2014). Existing studies have established a positive relationship between job satisfaction and performance (Judge et al., 2001). Harrison et al. (2006) argued that job satisfaction is also understood in terms of its relationship with other key factors of employees, like general well-being in the workplace, stress and workload, control at work, home-work balance and working conditions.

The relationship between job satisfaction and age shows that levels of job satisfaction tended to change, with initially high levels giving way to declines in mid-career, and then starting to improve again later in the worker's career. This was explained by an individual's adjustment to his/her work and life situation (Halkos and Bousinakis, 2010). In terms of occupational stress, previous research has shown that middle-aged workers (30 to 50-year-olds) had slightly higher proportions in the reported high stress category than those at the extremes of the age range (Smith et al., 2000). This could be explained by multiple family and work-related tasks that potentially impact the stress levels during one's middle-years (see, e.g., Darmody and Smyth, 2016). Also, a study conducted by Yang et al. (2016) reported that occupational stress decreases employees' occupational satisfaction and self-motivation.

Occupational stress and burnout impact the health and psychological well-being of workers with the attendant effects on their attitude towards work (Babajide and Akintayo, 2011). When the working environment is perceived to be conducive, there is less stress, employees are satisfied and job performance is greatly enhanced (Parkes, 2002). Burnout leads to lower productivity and effectiveness at work. It is associated with decreased job satisfaction and a reduced commitment to the job or the organization (Maslach et al., 2001).

\subsection{Age diversity in the workplace}

Population ageing is impacting employers, and for many organisations there are strong business reasons to develop strategies for managing diversified age profiles in their workplaces (Hoyle, 2017). Job characteristics are not experienced in the same way by all age diverse workers. Given the demographic shifts in today's workplace, a worker's age appears to be an important individual difference ( $\mathrm{Za}$ niboni et al., 2014).

On the one hand, high diversity in teams or other organizational units might increase creativity, innovation and problem solving due to the multiple perspectives and backgrounds of the different workers. On the other hand, high diversity often comes with higher needs for communication, coordination and conflict management due to differences in expectations, working styles and general values. Therefore, to benefit from diversity, the accurate management of mutual perceptions and interactions is crucial (Hertel et al., 2013).

Hertel et al. (2013) asserted that ageing refers to changes that occur in biological, psychological and social functioning over time, thereby affecting individuals 
on personal, organizational and societal levels. This also means that employees' age diversity has different effects on work-related attitudes. According to Schneid et al. (2018), understanding age diverse employees is essential for improving productivity and for ensuring the success of the company, which also leads to the well-being of all age diverse employees. Thus, on the basis of the literature review, we can summarize that age diverse employees are faced with different symptoms of burnout and occupational stress when carrying out their work.

\subsection{Research hypotheses}

Based on the theoretical ground, we formulated the following research hypotheses.

Hypotheses $\mathrm{H} 1$ is formed following Adams et al. (2013) and Hertel et al. (2013), who state that older employees report experiencing lower levels of stressors than younger employees. Adams et al. (2013) summarized two possible explanations for these findings. First, as employees age they accumulate more work experiences and acquire more occupational expertise and wisdom, which may act as a resource when dealing with role-related stressors. Second, older employees are more likely to be in high-status positions with certain characteristics, including job control, flexible work schedules and access to support from the job environment. These job characteristics may reduce employee exposure to stressors such as role ambiguity and role conflict.

H1: There are statistically significant differences in occupational stress in the workplace between older and younger employees.

Hypotheses H2.1, H2.2 and H2.3 were formed based on findings that showed age was differentially related to burnout in separate age groups (Ahola et al., 2008). The same approach when studying symptoms of burnout was used by Mosadeghrad (2014). The highest burnout prevalence was found among the younger employees. Haley et al. (2013) stated that possible reasons for younger employees' higher burnout levels seem to include a lack of skills to deal with everyday problems arising in the workplace, a "reality shock" when just entering the workplace, a lack of coping skills as a result of less experience in a working environment and transitional shock. On the other hand, Wang and Shultz (2010) emphasized that burnout increases with ageing. Among the demographic variables, age turns out to be the most related to burnout. It has been found that poor health is one of the major determinants of early retirement, and the poorer the health of older workers, the stronger their intentions appear to be to withdraw from the labour force early.

- H2.1: There are statistically significant differences in behavioral symptoms of burnout in the workplace between older and younger employees.

- H2.2: There are statistically significant differences in emotional symptoms of burnout in the workplace between older and younger employees.

- H2.3: There are statistically significant differences in physical symptoms of burnout in the workplace between older and younger employees.

Hypotheses H3.1, H3.2, H3.3, H3.4 and H3.5 were formed based on the findings of Fairbrother and Warn (2003), who found strong correlations between the dimensions of workplace, stress and job satisfaction. High levels of work stress are associated with low levels of job satisfaction. Job stressors are predictive for job dissatisfaction and a greater propensity to leave the organization. According to Faragher et al. (2005) occupational stress has a negative effect on job satisfaction and deteriorates the physical and mental health of age diverse employees. Lu and Gursoy (2013) summarized that all symptoms of burnout have a significant negative impact on the age diverse employees' work satisfaction.

- H3.1: Occupational stress has a significant impact on the employees' perceived work satisfaction.

- H3.2: Symptoms of behavioral burnout have a significant impact on the employees' perceived work satisfaction.

- H3.3: Symptoms of emotional burnout have a significant impact on the employees' perceived work satisfaction.

- H3.4: Symptoms of physical burnout have a significant impact on the employees' perceived work satisfaction.

- H3.5: Age has a significant impact on the employees' perceived work satisfaction

\section{Methodology}

\subsection{Data and sample}

A survey among Slovenian medium-sized (the average number of employees in business year does not exceed 250) and large companies (the average number of employees in business year exceeds 250) was conducted, and questionnaires were sent to 800 randomly selected medium-sized and large Slovenian companies. The questionnaire was addressed to the owner/manager of the company and sent via e-mail or ordinary post (depending on the availability of contact data). We asked the owner/manager of the company to distribute a questionnaire among age diverse employees. With the purpose of increasing the response rate, we sent the reminders to complete the questionnaire in three waves: twice by e-mails and once by personally contacting them by phone. The main survey involved 307 companies (the response rate was $38.4 \%$ ). We limited the responses to up to four employees in each company, and, thus, the survey included 691 respondents. 
The employees in the sample were divided into two age groups: younger employees under 50 years of age and older employees between 50 to 65 years of age. In most cases in the literature, the lower age limit defining older employees is 45 years (Brooke, 2003) or 50 years (Ilmarinen, 2001); the term "older employees" also refers to employees between 40 and 50 years of age (Ghosheh et al., 2006). For the purposes of the present research the age of 50 years is used. Table 1 shows the profile of respondents - employees with respect to control variables.

The survey responses included $47 \%$ younger employees aged 18 to 49 years and $52.8 \%$ older employees aged 50 to 65 . Regarding the achieved education level of employees who participated in the research, $62.7 \%$ of the respondents finished high professional or university education, $21.7 \%$ of the respondents have a master's degree or doctorate, $14.3 \%$ of the respondents finished college and the smallest percentage represents respondents who finished vocational or high school $(1.3 \%)$. The biggest share of responses represented large companies (51.9\%). Medium-sized companies comprised $48.1 \%$.

\subsection{Research instrument}

Statements included in the questionnaire, describing different dimensions of occupational stress and symptoms of burnout (behavioral symptoms, emotional symptoms and physical symptoms), were designed and tested in empirical research by Mosadeghrad (2014). Statements describing different dimensions of employee satisfaction were also designed and tested by Groot and Brink (1999). The respondents indicated their agreement to the listed statements, using a 5-point Likert-type scale from 1-completely disagree to 5-completely agree.

\subsection{Methods used}

Factor analysis was used to form multidimensional constructs for the perceived occupational stress, symptoms of burnout and perceived employees' satisfaction. We wanted to establish whether the use of factor analysis is reasonable on the basis of the Kaiser-Meyer-Olkin (KMO) measure of sampling adequacy $(\mathrm{KMO} \geq 0.5)$ (Kaiser, 1974) and Bartlett's test of sphericity. For the communalities the threshold of 0.40 was used (Costello and Osborne, 2005). The initial factors' rotation was conducted with the purpose to improve factors' interpretability and achieve a more even distribution of variance across factors. The rectangular rotation Varimax maximises the variance of weight squares in every factor, and that simplifies the structure by columns (Manly, 2005).

To test hypotheses H1, H2.1, H2.2 and $\mathrm{H} 2.3$ about the differences between younger and older employees, the non-parametric Mann-Whitney U test was used. To test hypothesis H3.1 - H3.5, about the impact of occupational stress, behavioral, emotional and physical symptoms of burnout and age on employees' work satisfaction, the multiple regression analysis was used.

\section{Results}

\subsection{Results of factor analysis}

First the factor analysis was applied to form the constructs of occupational stress, symptoms of the three groups of symptoms of burnout and employees' satisfaction. Results of the factor analysis are presented in Tables 1,2 and 3.

Table 1 shows the results of factor analysis for the construct occupational stress. Results of the KMO measure and the Bartlett's test of sphericity show that the use of factor analysis is justified. The values of all communalities in Table 1 for the construct occupational stress of age diverse employees are higher than 0.60 , therefore we have not eliminated any measured variables. Table 1 also shows that total variance explained is $72.7 \%$. All factor loadings are higher than 0.70 . In our case, the most important role in occupational stress of age diverse employees is achieved by the statement: "Due to stress in the workplace, I feel a lack of energy, tiredness". The value of the Cronbach's alpha for the factor occupational stress of age diverse employees is 0.940 , therefore the reliability of the measurement in occupational stress of age diverse employees is exemplary.

Table 2 shows the results of factor analysis for the constructs of burnout, where the three dimensions of burnout are analyzed: behavioral, emotional and physical symptoms.

The value of Kaiser-Meyer-Olkin measures of sampling adequacy and the results of Bartlett's test of sphericity $(p<0.01)$ justified the use of factor analysis. The values of all communalities for the construct symptoms of burnout are higher than 0.60 , therefore we have not eliminated any variable. The total variance explained for behavioral symptoms of burnout is $84.9 \%$, and for emotional symptoms of burnout it is $82.8 \%$. In the case of physical symptoms of burnout, two factors were obtained which together explain $85.3 \%$ of variability (first factor $74.8 \%$, second factor $10.4 \%$ ). Thus, we obtained two factors: physical symptoms of burnout-1 and physical symptoms of burnout-2.

In our case, the most important role in behavioral symptoms of burnout of age diverse employees is achieved by the statement: "I lack the will to socialize with co-workers" and the most important role in emotional symptoms of burnout by the statement: "I feel anger". The most important role in physical symptoms of burnout-1 (factor 1) is "I have vertigo". For physical symptoms of burnout- 2 the most important factor is "My sleep cycle is messy". 
Table 1: Results of factor analysis for the construct occupational stress

\begin{tabular}{|l|c|c|}
\hline \multicolumn{1}{|c|}{ Construct occupational stress } & Communalities & Factor loadings \\
\hline I am facing with the stress in performing work tasks. & 0.734 & 0.857 \\
\hline $\begin{array}{l}\text { Due to an excessive amount of work, my lifestyle is } \\
\text { rather uneven (irregular meals, an unsettled sleeping } \\
\text { cycle, lack of sports activity). }\end{array}$ & 0.685 & 0.828 \\
\hline $\begin{array}{l}\text { Due to stress in the workplace, I feel a lack of energy, } \\
\text { tiredness. }\end{array}$ & 0.813 & 0.901 \\
\hline $\begin{array}{l}\text { Due to stress in the workplace, I have problems with } \\
\text { concentration. }\end{array}$ & 0.719 & 0.848 \\
\hline $\begin{array}{l}\text { I feel the lack of my capacity in performing my work } \\
\text { tasks. }\end{array}$ & 0.782 & 0.884 \\
\hline $\begin{array}{l}\text { At workplace, the stance of my body is forced for a long } \\
\text { time (siting, standing). }\end{array}$ & 0.601 & 0.775 \\
\hline $\begin{array}{l}\text { At the workplace there is tension, conflict between } \\
\text { employees. }\end{array}$ & 0.754 & 0.868 \\
\hline Kaiser-Meyer-Olkin measure: 0.898 & Approximate & \\
\hline & Chi-Square & 2191.119 \\
\cline { 2 - 4 } & df & 0.000 \\
\hline \multirow{2}{*}{ Bartlett's test of sphericity } & & \\
\hline Cumulative percentage of explained variance: $72.675 \%$ & \\
\hline Cronbach's Alpha: 0.940 & & \\
\hline
\end{tabular}

The values of the Cronbach's alphas for all three constructs of burnout are high (over 0.9), indicating that the reliabilities of the measurement scales are again exemplary.

Table 3 shows the results of factor analysis for the construct employees' satisfaction. Again, the value of the Kaiser-Meyer-Olkin measure of sampling adequacy and the results of the Bartlett's test of sphericity $(p<0.01)$ justified the use of factor analysis. The values of all communalities were higher than 0.70 . The total variance explained for employees' satisfaction is $82.1 \%$. The most important role in satisfaction of employees is achieved by the statement: "At my workplace I am satisfied with the leadership in the company". The value of the Cronbach's alpha for the factor employees' satisfaction is 0.964 , therefore the reliability of the measurement in the satisfaction of employees is also exemplary.

\subsection{Differences between younger and older employees regarding the occupational stress and symptoms of burnout}

In the second step, the obtained factors were used to test the hypotheses $\mathrm{H} 1$ and $\mathrm{H} 2$, where older and younger employees were defined according to age group. Table 4 presents the results of the non-parametric Mann-Whitney U test of obtained factors for the construct occupational stress and the construct symptoms of burnout in the workplace.

By using the Mann-Whitney U test, we tested whether the observed differences between employees in the two age groups are statistically significant. Based on the results (Table 4), we found that there are statistically significant differences between older and younger employees in the levels of occupational stress as well as regarding the symptoms of burnout (behavioral symptoms of burnout, emotional symptoms of burnout and physical symptoms of burnout) in the workplace. Based on the results we confirmed the hypothesis H1: There are statistically significant differences in occupational stress in the workplace between older and younger employees and hypothesis H2.1: There are statistically significant differences in behavioral symptoms of burnout in the workplace between older and younger employees. We also confirmed hypothesis H2.2: There are statistically significant differences in emotional symptoms of burnout in the workplace between older and younger employees and hypothesis $\mathrm{H} 2.3$ : There are statistically significant differences in physical symptoms of burnout in the workplace between older and younger employees. We can also conclude that the perceived levels of occupational stress as well as perceived symptoms of burnout (behavioral, emotional and physical) are on average lower in the group of older employees as compared 
Table 2: Results of factor analysis for the construct symptoms of burnout

\begin{tabular}{|c|c|c|c|}
\hline Behavioral symptoms of burnout & Communalities & \multicolumn{2}{|c|}{ Factor loadings } \\
\hline I avoid activities. & 0.841 & \multicolumn{2}{|c|}{0.917} \\
\hline I have nightmares. & 0.863 & \multicolumn{2}{|c|}{0.929} \\
\hline I have insomnia. & 0.631 & \multicolumn{2}{|c|}{0.794} \\
\hline I have difficulties with concentration and memory. & 0.856 & \multicolumn{2}{|c|}{0.925} \\
\hline I wish for solitude. & 0.892 & \multicolumn{2}{|c|}{0.945} \\
\hline My working ability has declined. & 0.896 & \multicolumn{2}{|c|}{0.947} \\
\hline I lack the will to work. & 0.904 & \multicolumn{2}{|c|}{0.951} \\
\hline I lack the will to socialize with co-workers. & 0.910 & \multicolumn{2}{|c|}{0.954} \\
\hline \multicolumn{4}{|l|}{ Kaiser-Meyer-Olkin measure: 0.937} \\
\hline \multirow{3}{*}{ Bartlett's test of sphericity } & Approximate Chi-Square & \multicolumn{2}{|c|}{8379.298} \\
\hline & df & \multicolumn{2}{|c|}{28} \\
\hline & $p$ & \multicolumn{2}{|c|}{0.000} \\
\hline \multicolumn{4}{|l|}{ Cumulative percentage of explained variance: 84.905} \\
\hline \multicolumn{4}{|l|}{ Cronbach's Alpha: 0.968} \\
\hline Emotional symptoms of burnout & Communalities & \multicolumn{2}{|c|}{ Factor loadings } \\
\hline I have depressive feelings & 0.864 & \multicolumn{2}{|c|}{0.929} \\
\hline I am tense. & 0.594 & \multicolumn{2}{|c|}{0.771} \\
\hline I feel panic & 0.877 & \multicolumn{2}{|c|}{0.937} \\
\hline $\begin{array}{l}\text { I am afraid of losing the job or not finishing the work } \\
\text { on schedule. }\end{array}$ & 0.644 & \multicolumn{2}{|c|}{0.802} \\
\hline I am sad. & 0.834 & \multicolumn{2}{|c|}{0.913} \\
\hline I have a feeling of helplessness & 0.872 & \multicolumn{2}{|c|}{0.934} \\
\hline To me, everything seems meaningless & 0.890 & \multicolumn{2}{|c|}{0.943} \\
\hline I am emotionally exhausted & 0.864 & \multicolumn{2}{|c|}{0.930} \\
\hline I am exceedingly sensitive & 0.879 & \multicolumn{2}{|c|}{0.938} \\
\hline I am quarrelsome. & 0.891 & & \\
\hline I feel anger. & 0.901 & & \\
\hline Kaiser-Meyer-Olkin measure: 0.949 & & & \\
\hline & Approximate Chi-Square & & \\
\hline Bartlett's test of sphericity & df & & \\
\hline & $p$ & & \\
\hline Cumulative percentage of explained variance: 82.825 & & & \\
\hline Cronbach's Alpha: 0.977 & & & \\
\hline Physical symptoms of burnout & Communalities & Fact & hgs \\
\hline & & 1 & 2 \\
\hline I have headaches, migraines. & 0.814 & 0.283 & 0.857 \\
\hline My sleep cycle is messy. & 0.859 & 0.253 & 0.892 \\
\hline I have vertigo. & 0.948 & 0.917 & 0.327 \\
\hline I am sweating. & 0.938 & 0.914 & 0.320 \\
\hline I have sweaty and cold hands. & 0.937 & 0.913 & 0.323 \\
\hline My blood pressure varies. & 0.938 & 0.901 & 0.354 \\
\hline I often have the flu or virosis. & 0.770 & 0.690 & 0.542 \\
\hline
\end{tabular}


Table 2: Results of factor analysis for the construct symptoms of burnout (continued)

\begin{tabular}{|l|l|l|l|}
\hline I am often tired, exhausted. & 0.795 & 0.483 & 0.749 \\
\hline I have stomach aches. & 0.752 & 0.612 & 0.617 \\
\hline I have increased heart rate. & 0.835 & 0.739 & 0.538 \\
\hline I have lower back pain, shoulder pain. & 0.792 & 0.391 & 0.799 \\
\hline Kaiser-Meyer-Olkin measure: 0.934 & & \\
\hline
\end{tabular}

Table 3: Results of factor analysis for the construct employees' satisfaction

\begin{tabular}{|c|c|c|}
\hline At my workplace I am satisfied: & Communalities & Factor loadings \\
\hline $\begin{array}{l}\text { With working hours and distribution of work obliga- } \\
\text { tions. }\end{array}$ & 0.880 & 0.938 \\
\hline With flexible working hours. & 0.863 & 0.929 \\
\hline With the balance between work and private life & 0.659 & 0.812 \\
\hline $\begin{array}{l}\text { With enabled self-regulation of speed of work per- } \\
\text { formed. }\end{array}$ & 0.855 & 0.925 \\
\hline With intergenerational cooperation. & 0.880 & 0.938 \\
\hline $\begin{array}{l}\text { With the working conditions, such as better light, air } \\
\text { conditioning, and bigger inscriptions. }\end{array}$ & 0.723 & 0.851 \\
\hline With the interpersonal relationships in the company. & 0.828 & 0.910 \\
\hline With the leadership in the company & 0.882 & 0.939 \\
\hline \multicolumn{3}{|l|}{ Kaiser-Meyer-Olkin measure: 0.941} \\
\hline \multirow{3}{*}{ Bartlett's test of sphericity } & $\begin{array}{l}\text { Approximate } \\
\text { Chi-Square }\end{array}$ & 7211.576 \\
\hline & $\mathrm{df}$ & 28 \\
\hline & $p$ & 0.000 \\
\hline \multicolumn{3}{|l|}{ Cumulative percentage of explained variance: $82.130 \%$} \\
\hline \multicolumn{3}{|l|}{ Cronbach’s Alpha: 0.964} \\
\hline
\end{tabular}

Table 4: Mann-Whitney U test

\begin{tabular}{|c|c|c|c|c|c|c|}
\hline \multirow{2}{*}{\multicolumn{2}{|c|}{ Factors (constructs) }} & \multicolumn{2}{|c|}{ Mean } & \multirow{2}{*}{$\begin{array}{c}\text { Mann- } \\
\text { Whitney U }\end{array}$} & \multirow{2}{*}{ Z } & \multirow{2}{*}{$\begin{array}{l}\text { Asymp. Sig } \\
\text { (2-tailed) }\end{array}$} \\
\hline & & $\begin{array}{c}\text { Younger } \\
\text { employees }\end{array}$ & $\begin{array}{c}\text { Older } \\
\text { employees }\end{array}$ & & & \\
\hline \multicolumn{2}{|l|}{ Occupational stress } & -0.0069163 & -0.1256373 & 46526.000 & -4.775 & 0.000 \\
\hline \multicolumn{2}{|c|}{ Behavioral symptoms of burnout } & 0.0337975 & -0.0630286 & 49436.000 & -3.599 & 0.000 \\
\hline \multicolumn{2}{|c|}{ Emotional symptoms of burnout } & 0.0490263 & -0.0468914 & 48887.000 & -3.638 & 0.000 \\
\hline \multirow{2}{*}{$\begin{array}{l}\text { Physical symptoms of } \\
\text { burnout }\end{array}$} & Factor 1 & 0.0380275 & -0.1218029 & 113750.500 & -4.357 & 0.000 \\
\hline & Factor 2 & -0.0027594 & -0.2210989 & 110419.500 & -5.644 & 0.000 \\
\hline
\end{tabular}

to the group of younger employees (average factors' values are lower for older employees), which is in line with several previous findings (Mosadeghrad, 2014; Henkens and Leenders, 2010; Maslach et al., 2001; Schaufeli and Enzmann, 1998; Campanelli, 1990).

To further illustrate these results, Table 5 presents the non-parametric Mann-Whitney $U$ test of individual com- ponents for the construct occupational stress and Table 6 presents the non-parametric Mann-Whitney $U$ test of the age diverse employees of individual components for constructs of behavioral, emotional and physical symptoms of burnout.

Based on the results (Table 5), we found there are statistically significant differences between older and young- 
Table 5: Mann-Whitney U Test for individual components of the constructs of occupational stress of younger and older employees

\begin{tabular}{|l|c|c|c|c|c|}
\hline \multirow{2}{*}{ Statement } & \multicolumn{2}{|c|}{ Mean } & \multicolumn{1}{c|}{$\begin{array}{c}\text { Mann- } \\
\text { Whitney U }\end{array}$} & Z & $\begin{array}{c}\text { Asymp. } \\
\text { Sig. } \\
\text { (2-tailed) }\end{array}$ \\
\cline { 2 - 5 } & $\begin{array}{c}\text { Younger } \\
\text { employees }\end{array}$ & $\begin{array}{c}\text { Older } \\
\text { employees }\end{array}$ & & & \\
\hline $\begin{array}{l}\text { I am facing with the stress in performing } \\
\text { work tasks. }\end{array}$ & 3.68 & 3.66 & 56510.500 & -1.167 & 0.243 \\
\hline $\begin{array}{l}\text { Due to an excessive amount of work, } \\
\text { my lifestyle is rather uneven (irregular } \\
\text { meals, an unsettled sleeping cycle, lack } \\
\text { of sports activity). }\end{array}$ & 3.69 & 3.59 & 43504.000 & -6.277 & 0.000 \\
\hline $\begin{array}{l}\text { Due to stress in the workplace, I feel a } \\
\text { lack of energy, tiredness. }\end{array}$ & 3.25 & 3.24 & 56846.500 & -0.990 & 0.322 \\
\hline $\begin{array}{l}\text { Due to stress in the workplace, I have } \\
\text { problems with concentration. }\end{array}$ & 2.52 & 2.59 & 39169.500 & -8.534 & 0.000 \\
\hline $\begin{array}{l}\text { I feel the lack of my capacity in perform- } \\
\text { ing my work tasks }\end{array}$ & 2.76 & 2.81 & 43564.500 & -6.598 & 0.000 \\
\hline $\begin{array}{l}\text { At workplace, the stance of my body is } \\
\text { forced for a long time (siting, standing). }\end{array}$ & 3.68 & 3.63 & 50059.500 & -3.772 & 0.058 \\
\hline $\begin{array}{l}\text { At the workplace there is tension, con- } \\
\text { flict between employees. }\end{array}$ & 3.05 & 3.03 & 48800.500 & -4.191 & 0.064 \\
\hline
\end{tabular}

er employees regarding the statement "Due to an excessive amount of work, my lifestyle is rather uneven (irregular meals, an unsettled sleeping cycle, lack of sports activity)", where older employees on average perceive a lower level of stress, as compared to younger employees. On the other hand, significant differences are found also regarding the statements "Due to stress in the workplace, I have problems with concentration" and "I feel the lack of my capacity in performing my work tasks" ( $p<0.05)$, where older employees on average perceive slightly higher levels of stress, as compared to younger employees. Other differences are not statistically significant $(p>0.05)$.

Table 6 presents the non-parametric Mann-Whitney $\mathrm{U}$ test results of the age diverse employees for individual components for constructs of behavioral, emotional and physical symptoms of burnout.

For all statements regarding the physical symptoms of burnout, where the significant differences are found, the average levels of agreement with the individual statements in the group of older employees are again lower than compared to those of younger employees, which is in line with the research results presented in the literature (Maslach et al., 2001). Statistically significant differences between older and younger employees regarding the physical symptoms of burnout are identified at the following items: "I have headaches, migraines", "My sleep cycle is messy", "I have vertigo", "I am sweating", "I have sweaty and cold hands", "I often have the flu or virus" and "I have stomach aches" $(p<0.05)$.

For each and every individual statement of the behav- ioral symptoms of burnout the average levels of agreement, indicating the perceived level of burnout, are lower for older employees. Statistically significant differences are identified regarding the following items: "I avoid activities", "I have difficulties with concentration and memory", "I wish for solitude" and "My working ability has declined" $(p<0.05)$.

Also there are statistically significant differences between older and younger employees in statements that describe emotional symptoms of burnout: "I feel panic", "I am sad", "To me, everything seems meaningless", "I am exceedingly sensitive", "I am quarrelsome" and "I feel anger" $(p<0.05)$, with on average lower levels observed in a group of older employees. Similarly, at all other statements the average levels of agreement for older employees are lower than compared to younger employees, but differences are not statistically significant $(p>0.05)$.

\subsection{The impact of occupational stress, symptoms of burnout and age on the employees' perceived work satisfaction}

In the continuation we present the results of testing hypothesis H3, which was elaborated into the form of five sub-hypotheses:

- H3.1: Occupational stress has a significant impact on the employees' perceived work satisfaction. 
Table 6: Mann-Whitney U Test for individual components of the constructs of the three groups symptoms of burnout of younger and older employees

\begin{tabular}{|c|c|c|c|c|c|}
\hline & \multicolumn{2}{|c|}{ Mean } & \multirow{2}{*}{$\begin{array}{l}\text { Mann- } \\
\text { Whitney U }\end{array}$} & \multirow{2}{*}{$\mathrm{Z}$} & \multirow{2}{*}{$\begin{array}{c}\text { Asymp. } \\
\text { Sig. } \\
\text { (2-tailed) }\end{array}$} \\
\hline & $\begin{array}{c}\text { Younger } \\
\text { employees }\end{array}$ & $\begin{array}{c}\text { Older } \\
\text { employees }\end{array}$ & & & \\
\hline \multicolumn{6}{|l|}{ Physical symptoms of burnout } \\
\hline I have headaches, migraines. & 3.50 & 3.38 & 50311.500 & -3.559 & 0.000 \\
\hline My sleep cycle is messy. & 3.69 & 3.60 & 50866.500 & -3.353 & 0.001 \\
\hline I have vertigo. & 2.61 & 2.52 & 54122.500 & -2.124 & 0.034 \\
\hline I am sweating. & 2.64 & 2.52 & 53833.500 & -2.233 & 0.026 \\
\hline I have sweaty and cold hands. & 2.57 & 2.48 & 52387.500 & -2.853 & 0.004 \\
\hline My blood pressure varies. & 2.72 & 2.76 & 58860.500 & -0.181 & 0.856 \\
\hline I often have the flu or virosis. & 2.98 & 2.91 & 53367.500 & -2.312 & 0.021 \\
\hline I am often tired, exhausted. & 3.44 & 3.31 & 54775.500 & -1.746 & 0.081 \\
\hline I have stomach aches. & 3.09 & 2.88 & 47977.500 & -4.286 & 0.000 \\
\hline I have increased heart rate. & 2.90 & 2.85 & 55051.000 & -1.575 & 0.115 \\
\hline I have lower back pain, shoulder pain. & 3.56 & 3.53 & 58401.500 & -0.362 & 0.718 \\
\hline \multicolumn{6}{|l|}{ Behavioral symptoms of burnout } \\
\hline I avoid activities. & 2.70 & 2.60 & 51006.000 & -3.289 & 0.001 \\
\hline I have nightmares. & 2.78 & 2.72 & 54897.500 & -1.735 & 0.083 \\
\hline I have insomnia. & 3.43 & 3.38 & 54459.000 & -1.933 & 0.053 \\
\hline $\begin{array}{l}\text { I have difficulties with concentration and } \\
\text { memory. }\end{array}$ & 2.51 & 2.43 & 53556.500 & -2.321 & 0.020 \\
\hline I wish for solitude. & 2.54 & 2.44 & 51623.000 & -3.092 & 0.002 \\
\hline My working ability has declined. & 2.88 & 2.76 & 53870.000 & -2.118 & 0.034 \\
\hline I lack the will to work. & 2.72 & 2.65 & 56190.000 & -1.176 & 0.240 \\
\hline $\begin{array}{l}\text { I lack the will to socialize with co-work- } \\
\text { ers. }\end{array}$ & 2.65 & 2.58 & 55095.500 & -1.557 & 0.120 \\
\hline \multicolumn{6}{|l|}{ Emotional symptoms of burnout } \\
\hline I have depressive feelings. & 2.42 & 2.36 & 58017.500 & -0.522 & 0.602 \\
\hline I am tense. & 3.46 & 3.38 & 55109.500 & -1.611 & 0.107 \\
\hline I feel panic. & 2.50 & 2.39 & 53193.500 & -2.531 & 0.011 \\
\hline $\begin{array}{l}\text { I am afraid of losing the job or not finish- } \\
\text { ing the work on schedule. }\end{array}$ & 2.83 & 2.92 & 57005.000 & -0.922 & 0.357 \\
\hline I am sad. & 2.61 & 2.58 & 52485.000 & -2.702 & 0.007 \\
\hline I have a feeling of helplessness. & 2.43 & 2.34 & 55874.500 & -1.415 & 0.157 \\
\hline To me, everything seems meaningless. & 2.35 & 2.29 & 53790.000 & -2.304 & 0.021 \\
\hline I am emotionally exhausted. & 2.72 & 2.67 & 58959.500 & -0.068 & 0.946 \\
\hline I am exceedingly sensitive. & 2.64 & 2.55 & 53106.000 & -2.410 & 0.016 \\
\hline I am quarrelsome. & 2.58 & 2.47 & 51569.500 & -3.128 & 0.002 \\
\hline I feel anger. & 2.52 & 2.42 & 49988.500 & -3.782 & 0.000 \\
\hline
\end{tabular}


Table 7: Multiple regression results

\begin{tabular}{|c|c|c|c|c|c|c|c|}
\hline \multirow[t]{2}{*}{ Model } & \multicolumn{2}{|c|}{$\begin{array}{l}\text { Unstandardized } \\
\text { Coefficients }\end{array}$} & \multirow{2}{*}{$\begin{array}{c}\text { Standardized } \\
\text { Coefficients }\end{array}$} & \multirow[t]{2}{*}{$\mathrm{t}$} & \multirow{2}{*}{ Sig. } & \multicolumn{2}{|c|}{ Collinearity Statistics } \\
\hline & B & Std. Error & & & & Tolerance & VIF \\
\hline (Constant) & 0.178 & 0.036 & & 4.973 & 0.000 & & \\
\hline Stress & -0.459 & 0.061 & -0.459 & -7.540 & 0.000 & 0.433 & 2.310 \\
\hline $\begin{array}{l}\text { Behavioral symptoms } \\
\text { of burnout }\end{array}$ & -0.284 & 0.084 & -0.285 & -3.378 & 0.001 & 0.954 & 1.048 \\
\hline $\begin{array}{l}\text { Emotional symptoms } \\
\text { of burnout }\end{array}$ & -0.147 & 0.079 & -0.147 & -1.864 & 0.003 & 0.963 & 1.038 \\
\hline $\begin{array}{l}\text { Physical symptoms of } \\
\text { burnout } 1\end{array}$ & 0.042 & 0.040 & 0.043 & 1.057 & 0.291 & 0.403 & 2.480 \\
\hline $\begin{array}{l}\text { Physical symptoms of } \\
\text { burnout } 2\end{array}$ & 0.060 & 0.043 & 0.060 & 1.398 & 0.162 & 0.373 & 2.684 \\
\hline Age & -0.328 & 0.051 & -0.164 & -6.490 & 0.000 & 0.978 & 1.023 \\
\hline
\end{tabular}

- H3.2: Symptoms of behavioral burnout have a significant impact on the employees' perceived work satisfaction.

- H3.3: Symptoms of emotional burnout have a significant impact on the employees' perceived work satisfaction.

- H3.4: Symptoms of physical burnout have a significant impact on the employees' perceived work satisfaction.

- H3.5: Age has a significant impact on the employees' perceived work satisfaction.

The multiple regression model was formed, where the dependent variable was the multidimensional construct (factor) for employees' satisfaction, while the explanatory variables included in the model were constructs (factors) for occupational stress and burnout (physical, behavioral and emotional). The age differences were studied by the inclusion of the dummy variable age $(0$ - older and $1-$ younger employees) into the regression model. Results are presented in Table 7.

Multiple regression results show that the regression model is significant $(F=181.765, p<0.01)$ and that over $60 \%$ of variance of a dependent variable is explained by the regression model (Adjusted $\mathrm{R}$ square $=0.618$ ). Values of tolerance and the variance inflation factor (VIF) indicate no significant multicollinearity problems among variables. The cutoff for VIF $<5$ is used (Sheather, 2009).

Results also reveal that the impact of occupational stress of employees on their work satisfaction is, as expected, negative. The higher the perceived stress, the lower on average the employees' work satisfaction; the impact is significant $(p<0.05)$. Therefore, hypothesis H3.1 is confirmed.
Behavioral and emotional symptoms of burnout also proved to have a significant and negative impact on employees' satisfaction $(p<0.05)$; employees perceiving higher levels of behavioral and emotional symptoms of burnout, are on average, less satisfied with their work. Therefore, hypotheses H3.2 and H3.3 are confirmed. On the other hand, the physical symptoms of burnout were not identified as an important factor of employees' work satisfaction (for both factors $p<0.05$ ), thus hypothesis H3.4 in not confirmed. According to Veromaa et al. (2017) work ability is the degree to which an employee, given his/her health, is physically and mentally able to cope with the demands at work. On the other hand, work satisfaction and work engagement are more dependent on mental or emotional aspects.

Age is a significant factor shaping the employees' perceived work satisfaction - research results show that the regression coefficient for age variable is significant and negative $(p<0.05)$, confirming that the level of work satisfaction for younger employees is on average lower than compared to their older counterparts. As already mentioned, the perceived occupational stress and perceived burnout are significantly higher in the group of younger employees, thus it is not surprising that these characteristics are also reflected in their lower perceived satisfaction with work. Therefore, hypothesis H3.5 is confirmed.

\section{Discussion and conclusion}

Based on the results, we found there are statistically significant differences between older and younger employees relating to occupational stress as well as regarding the behavioral, emotional and physical symptoms of burnout 
in the workplace (Table 4). Results also revealed that the perceived levels of occupational stress as well as perceived symptoms of burnout (behavioral, emotional and physical) are on average lower in the group of older employees than compared to the group of younger employees, which is in line with several previous findings (Mosadeghrad, 2014; Henkens and Leenders, 2010; Maslach et al., 2001; Schaufeli and Enzmann, 1998; Campanelli, 1990). This at the same time provides the answers to the first two research questions: we established the statistically significant differences in occupational stress and in symptoms of burnout in the workplace of older employees as compared to younger employees in Slovenian companies.

Research results also show that the impact of employees' occupational stress on their work satisfaction is significant and negative (the higher the perceived stress, the lower on average the employees' work satisfaction). Behavioral and emotional symptoms of burnout also proved to have a significant and negative impact on employees' satisfaction, while physical symptoms of burnout do not. Employees perceiving higher levels of behavioral and emotional symptoms of burnout, are on average, less satisfied with their work. Age is a significant factor shaping the employees' perceived work satisfaction. Research results show that the regression coefficient for age variable is significant and negative, confirming that the level of work satisfaction for younger employees is on average lower than compared to their older counterparts (Table 7). The perceived occupational stress and perceived symptoms of burnout are significantly higher in the group of younger employees (Table 5 and Table 6), which is in line with several previous findings (Adams et al., 2013; Ahola et al., 2008; Haley et al., 2013). This also brings the answer to the third research question: we established that occupational stress, behavioral and emotional symptoms of burnout and age proved to have a significant and negative impact on employees' satisfaction, while the impact of physical symptoms of burnout was not confirmed.

The demographics of the global workforce are changing, specifically with a more age diverse workforce, bringing new research questions. It becomes more important to find ways for people to stay satisfied in their work at different life stages. The quality of working life has a big impact on all employees because we spend so much of our time at work. Therefore, investments in active ageing need to be secured during the working years.

Our study has several implications for employers and policymakers. Recommendations for employers that reduce occupational stress and symptoms of burnout for age diverse employees include redesign of the workplace (re-designing individual work tasks according to the needs and capabilities of employees), job simplification, job rotation, redistribution in the company (coordinating job requirements with the capabilities and skills of employees), job sharing and providing more frequent short breaks at work. For economic policymakers the main implication is the need to formulate legislative measures that allow for more flexible forms of employment of a younger generation. Working conditions must be adapted to all employees; workplaces should be developed according to the age diversity of employees, with the workload adapted to all age groups. It is important to know that job characteristics are not experienced in the same way by all employees. From this perspective, our research shows the importance of well-being, health and a friendly work environment for age diverse employees in Slovenian companies.

Our study is limited to the focus of age differences among employees in Slovenia in medium-sized and large Slovenian companies. Further research may investigate in more detail the importance of control variables that are not included in the model, for example, gender, education or industry, as well as gender differences in the respective age groups. The multidimensional constructs included in our research model are the perceived occupational stress, symptoms of behavioral, emotional and physical burnout and work satisfaction that are limited to the work place situations. Further research may also include dimensions of individuals' lives; for example, we can assume that a great deal of stress of younger generations can be attributed to the greater dynamics and difficulties in balancing private-family care and employment. Therefore, for economic policy makers it could also be important to establish the importance of affordable, and, above all, safe, childcare. Allowing different precarious forms of employment, which the younger generations in Slovenia witness to a great extent, does not help to regulate the situation in this field, nor to create a balance between the family and the employment environment. Temporary contracts for employment are extremely common among young people in Slovenia; data show that in Slovenia the incidence of temporary contracts among young people is much higher (over $70 \%$ ) as compared to OECD averages for the same age group (approximately 25\%) (OECD, 2015). The negative effects of precariat are numerous and contribute to occupational stress and burnout: uncertainty, low pay, limited social security rights, mostly short-term work, flexibility on the part of an employee in terms of adapting to the needs of employers, etc. This is also an important area for further research - if further research confirms that occupational stress and burnout are deepened by the precarious forms of employment, then economic and social policy measures should pay more attention to this area immediately. From the methodological viewpoint, further research may include the development of a conceptual model using the structural equation modeling (SEM) approach. A multisample analysis may be recommended in the structural model to examine differences by age in the paths. 


\section{References}

Adams, G. A., DeArmond, S., Jex, S. M., Webster, J. R. (2013). Older Workers, Occupational Stress and Safety. Retrieved from https://www.researchgate.net/ publication/278847873 OLDER WORKERS OCCUPATIONAL_STRESS_AND_SAFETY (Accessed 7.1.2019).

Ahola, K., Honkonen, T., Virtanen, M., Aromaa, A., Lönnqvist, J. (2008).Burnout in Relation to Age in the Adult Working Population. Journal of Occupational Health, 50 (4), 362-365, http://doi.org/10.1539/joh.M8002

Campanelli, L. (1990). The Ageing Workforce: Implications for Organisations, Department of Health and Fitness. American University, 5 (4), 817-826.

Darmody, M., Smyth, E. (2016). Primary school principals, job satisfaction and occupational stress. International Journal of Educational Management, 30 (1), 115-128, https://doi.org/10.1108/IJEM-12-2014-0162

De Silva, N., Samanmali, R., De Silva, H. L. (2017). Managing occupational stress of professionals in large construction projects. Journal of Engineering, Design and Technology, 15 (4), 488-504, http://dx.doi. org/10.1108/JEDT-09-2016-0066

Fairbrother, K., Warn, J. (2003). Workplace dimensions, stress and job satisfaction. Journal of Managerial Psychology, 18 (1), 8-21, https://doi. org/10.1108/02683940310459565

Faragher, E. B, Cass, M., Cooper, C. L. (2005). The relationship between job satisfaction and health: a meta-analysis. Occupational and Environmental Medicine, 62 (2), 105-112, http://dx.doi.org/10.1136/ oem.2002.006734

George, E., Zakkariya K. A. (2015). Job related stress and job satisfaction: a comparative study among bank employees. Journal of Management Development, 34 (3), 316-329, https://doi.org/10.1108/JMD-07-2013-0097

Götz, S., Hoven, H., Müller, A., Dragano, N., Wahrendorf, M. (2018). Age differences in the association between stressful work and sickness absence among full-time employed workers: evidence from the German socio-economic panel. International Archives of Occupational and Environmental Health, 91, 479-496, http://doi.org/10.1007/s00420-018-1298-3

Haley, L. M., Mostert, K., Els, C. (2013). Burnout and Work Engagement for Different Age Groups: Examining Group-Level Differences and Predictors. Journal of Psychology in Africa, 23 (2), 283-296, http://doi.org /10.1080/14330237.2013.10820625

Halkos, G., Bousinakis, D. (2010). The Effect of Stress and Satisfaction on Productivity. International Journal of Productivity and Performance Management, 59 (5), 415-431, https://doi.org/10.1108/17410401011052869

Harrison, D. A., Newman, D.A., Roth, P.L. (2006). How important are job attitudes? Meta-analytic comparisons of integrative behavioral outcomes and time se- quences. Academy of Management Journal, 49 (2), pp. 305-326, https://doi.org/10.5465/AMJ.2006.20786077

Henkens, K., Leenders, M. (2010). Burnout and older workers' intentions to retire. International Journal of Manpower, 31 (3), 306-321, https://doi. org/10.1108/01437721011050594

Hertel, G., Béatrice I.J.M.H, Lange, A. H., Deller, J. (2013). Facilitating age diversity in organizations part II: managing perceptions and interactions. Journal of Managerial Psychology, 28 (7/8), 857-866.

Hertel, G., Thielgen, M., Rauschenbach, C., Grube, A., Stamov-Roßnagel, C., Krumm, S. (2013). Age Differences in Motivation and Stress at Work. Retrieved from https://www.researchgate.net/publication/256677456 Age Differences in Motivation and Stress at Work (Accessed 8.1.2019)

Hespanhol, A. (2004). Burnout e stress ocupacional. Revista Portuguesa de Psicossomática, 7 (1), 153-162.

Garg, P., Rastogi, R. (2006). New model of job design: Motivating employees' performance. Journal of Management Development, 25(6), 572-587, http://doi. org/10.1108/02621710610670137

Hoyle, R. (2017). Learning strategies for a changing workforce. Strategic HR Review, 16 (6), 255-260, https:// doi.org/10.1108/SHR-08-2017-0052

Ilmarinen, J. (2006). Towards a longer worklife! Ageing and the quality of worklife in the European Union«, Finnish Institute of Occupational Health. Retrieved from www.sopol.at/document/download/towards-alonger-worklife (Accessed 13.10.2018)

Jolynn, C., Becky, K., Rhett, K., Chad, A. (2011). Getting to grips with stress in the workplace: Strategies for promoting a healthier, more productive environment. Human Resource Management International Digest, 19 (4), 32-38, https://doi.org/10.1108/09670731111140748

Judge, T. A., Thoresen, C. J., Bono, J. E., Patton, G.K. (2001). The job satisfaction-job performance relationship: a qualitative and quantitative review. Psychological Bulletin, 127 (3), 376-407.

Kang, M. G., Koh, S. B., Cha, B. S., Park, J. K., Baik, S. K., Chang, S. J. (2005). Job stress and cardiovascular risk factors in male workers. Preventive Medicine, 40 (5), 583-588, https://doi.org/10.1016/j.ypmed.2004.07.018

Lu, A. C. C., Gursoy, D. (2013). Impact of Job Burnout on Satisfaction and Turnover Intention: Do Generational Differences Matter? Journal of Hospitality \& Tourism Research, 40 (2), 1-26, https://doi. org/10.1177/1096348013495696

Malik, O. F., Waheed, A., Malik, K. U. R. (2010). The mediating effects of job satisfaction on role stressors and affective commitment. International Journal of Business and Management, 5 (11), 223-235.

Maslach, C., Schaufeli, W. B., Leiter, M. P. (2001). Job burnout. Annual Review of Psychology, 52, 397-422, doi: https://doi.org/10.1146/annurev.psych.52.1.397

Morgeson, F. P., Humphrey, S. E. (2006). The Work De- 
sign Questionnaire (WDQ): Developing and Validating a Comprehensive Measure for Assessing Job Design and the Nature of Work. Journal of Applied Psychology, 91 (6), 1321-1339, https://doi.org/10.1037/00219010.91.6.1321

Mosadeghrad, A.M. (2014). Occupational Stress and its Consequences: Implications for Health Policy and Management. Leadership in Health Services, 27 (3), 224-239, https://doi.org/10.1108/LHS-07-2013-0032

O'Connor, B., White, B., Bundred, D. (2000). Theeffect of jobstrainon British general practitioners' mental health. Journal of Mental Health, 9 (6), 637-654.

OECD. (2015). Slovenia Policy Brief: Employment. Retrieved from https://www.oecd.org/policy-briefs/slovenia-active-labour-market-policies-to-fight-unemployment.pdf (Accessed 28.10.2018)

Parkes, H. L. (2002). Human health and management. London: Macmillan Press Ltd.

Robertson, I. T, Cooper, C. L. (2010). Full engagement: the integration of employee engagement and psychological well-being. Leadership \& Organization Development Journal, 31 (4), 324-336, https://doi. org/10.1108/01437731011043348

Schaufeli, W., Enzmann, D. (1998). The Burnout Companion to Study \& Practice: A Critical Analysis. London: Taylor \& Francis.

Schneid, M., Isidor, R., Steinmetz, H., Kabst, R. (2016). Age diversity and team outcomes: a quantitative review. Journal of Managerial Psychology, 31 (1), 2-17, https://doi.org/10.1108/JMP-07-2012-0228

Sheather, S. (2009). A modern approach to regression with $R$. New York, NY: Springer

Tansel, A., Gazîoğlu, S. (2014). Management-employee relations, firm size and job satisfaction. International Journal of Manpower, 35 (8), 1260-1275, https://doi. org/10.1108/IJM-09-2014-0179

Truxillo, D. M., Cadiz, D. M., Rineer, J. R., Zaniboni, S., Fraccaroli, F. (2012). A Lifespan Perspective on Job Design: Fitting the Worker to the Job to Promote Job Satisfaction, Engagement, and Performance. Organizational Psychology Review, 2 (4), 340-360, https:// doi.org/10.1177/2041386612454043

Veromaa V, Kautiainen H., Korhonen P. E. (2017). Physical and mental health factors associated with work engagement among Finnish female municipal employees: a cross-sectional study. BMJ open, 7 (10), 1-8, http://doi.org/10.1136/bmjopen-2017-017303

Wang, M., \& Shultz, K. S. (2010). Employee retirement: A review and recommendations for future investigation. Journal of Management, 36 (1), 172-206, https://doi. org/10.1177/0149206309347957

Yang, H., Ju, Y., Lee, Y. (2016). Effects of job stress on self-esteem, job satisfaction, and turn over intention. Journal of Transnational Management, 21 (1), 29-39, https://doi.org/10.1080/15475778.2016.1120613

Yavas, U., Babakus, E., Karatepe, O.M. (2013). Does hope moderate the impact of job burnout on frontline bank employees in-role and extra-role performances? International Journal of Bank Marketing, 31 (1), 56-70, https://doi.org/10.1108/02652321311292056

Zaniboni, S., Truxillo, D. M., Fraccaroli, F., McCune, E. A., Bertolino, M. (2014). Who Benefits from More Tasks? Older Versus Younger Workers. Managerial Psychology, 29 (5), 523-508, https://doi.org/10.1108/ JMP-12-2012-0381

Maja Rožman has acquired her Master degree at the Faculty of Economics and Business in Maribor at the Department of Finance and the PhD at the Department of Management and Organization. She is also a teaching assistant at the Faculty of Economics and Business at the Department of Quantitative Economic Analyses. Her research work is focused on contemporary management problems in organisations, especially in the field of human resource management. She is interested in entrepreneurial research in the field of family businesses and on quantitative methods in economics and business sciences.

Anastasiia Grinkevich, PhD, is an associate professor at the Department of Economics in Institute of Economics and Management, National Research Tomsk State University. Her current research interests are mainly focused on problems of financial management and tax policy efficiency and assessing the impact of tax incentives for small and innovative businesses. She is an author or co-author of over 30 scientific papers, with several of them in the Scopus or WoS databases, 6 monograph publications. The results of scientific work were presented at more than 10 conferences of different level: regional, national, international.

Polona Tominc, PhD, is a full-time Professor in the Department of Quantitative Economic Analysis at the Faculty of Economics and Business, University of Maribor. Her research is focused on statistical methods in economics and business sciences, especially in the field of entrepreneurship, gender differences and behavioural differences between social groups in different fields of management. She has published over sixty original scientific papers, with several of them in the Scopus or WoS databases and has participated at several scientific conferences. She is an author or coauthor of monograph publications and of chapters in scientific monographs. She is a team member of DIANA international research group, aimed at researching women entrepreneurship and a member of Global Entrepreneurship Monitor Slovenia research team. She leads the research program "Entrepreneurship for Innovative society". 